\title{
PENGARUH PENAMBAHAN BAKTERI PROBIOTIK DAN SUMBER CARBON DALAM SISTEM BIOFLOK TERHADAP FCR IKAN NILA LARASATI (OREOCHROMIS SP.)
}

\author{
Titin Liana Febriyanti ${ }^{1}$, Suminto ${ }^{2}$, Sutrisno Anggoro $^{3}$ \\ 1) Program Studi Budidaya Periaran Fakultas IImu-IImu Pertanian, \\ Universitas Muhammadiyah Gorontalo \\ 2) Fakultas Perikanan dan IImu Kelautan Universitas Diponegoro Semarang \\ 3) Fakultas Perikanan dan Ilmu Kelautan Universitas Diponegoro Semarang \\ E-Mail: iti86tolaki@gmail.com
}

\begin{abstract}
The high demand for fish consumption, especially freshwater fish, make cultivator developing aquaculture especially intensive systems, but constrained by various problems. Such as environmental pollution and increased cases of diseases. Then the need for such a solution that is like biofloc cultivation system. The purpose of this research is to know the combination of optimal biofloc system treatment for Tilapia fish (Oreochromis sp.) FCR (Feed Conversion Ratio). The experimental design used in this study was factorial design, with three repetitions. Factor 1 (ratio C: N), which consists of 3 levels C: N: 12, 18, and 24; Factor 2 (concentration of probiotic bacteria), which consists of two levels of $10^{6}$ and $10^{8} \mathrm{CFU} / \mathrm{ml}$. This study consisted of six treatments namely A1B1 (ratio C: $\mathrm{N} 12+$ bacterium $10^{6} \mathrm{cfu} / \mathrm{ml}$ ); A1B2 (ratio C: $\mathrm{N} 12+$ bacterium $10^{8} \mathrm{cfu} / \mathrm{ml}$ ); A2B1 (ratio C: $\mathrm{N} 18+$ bacteria $10^{6} \mathrm{cfu}$ / ml); A2B2 (ratio C: N $18+$ bacteria $10^{8} \mathrm{cfu} / \mathrm{ml}$ ); A3B1 (ratio C: $\mathrm{N} 24$ + bacteria $10^{6}$ $\mathrm{cfu} / \mathrm{ml}$ ); A3B2 (ratio C: N $24+$ bacteria $10^{8} \mathrm{cfu} / \mathrm{ml}$ ). The parameter observed is the FCR. The results of this study is the highest FCR on the C / N treatment Ratio 24 and at the density of probiotic bacteria $10^{8} \mathrm{CFU} / \mathrm{ml}$ that is equal to 1.69 .
\end{abstract}

Keywords: Intensive cultivation, C / N Ratio, probiotic bacteria, FCR

\section{PENDAHULUAN}

Masyarakat Indonesia yang mulai gemar mengkonsumsi ikan sebagai sumber protein hewaniseperti ikan nila.Sektor budidaya ikan nila telah dikembangkan di berbagai wilayah Indonesia, diantaranya adalah Aceh, Jawa Tengah, Jawah Barat, Sumatera Utara dan Lampung. Tingginya permintaan ikan konsumsi mendorong dilakukannya budidaya secara intensif untuk memenuhi pasar. Oleh karena itu, para petani budidaya mulai berupaya untuk mengembangkan perikanan budidaya terutama sistem intensif hingga kini masih terus dilakukan, tetapi terkendala oleh berbagai masalah (FAO, 2007).

Menurut Asaduzzaman et al. (2008) dan De Schryver et al (2008), tingginya penggunaan 
pakan buatan pada budidaya intensif menyebabkan pencemaran lingkungan dan peningkatan kasus penyakit, yang disebabakan karena limbah organik hasil dari sisa pakan, feses dan sisa metabolisme ikan. Total pakan yang diberikan hanya $20-25 \%$ yang dicerna ikan dan sisanya dibuang sebagai limbah organik yang umumnya didominasi oleh senyawa nitrogen anorganik yang beracun (Avnimelech dan Ritvo, 2003). Maka dari permaslahan tersebut diatas ini akan timbul dua masalah besar yaitu menurunnya pemanfaatan pakan dan penurunan kualitas air

$$
\text { Uapaya yang dapat }
$$
dilakukan dalam mengatasi masalah-masalah tersebut adalah dengan menggunakan sistem bioflok. Menurut Avinemelech (2009), bahwa teknologi bioflok mampu meningkatkan sistem imun pada tilapia dan udang vanamei. Selain dapat menurunkan limbah nitrogen anorganik, teknologi ini juga dapat menyediakan pakan tambahan berprotein sehingga dapat menaikan pertumbuhan dan efisiensi pakan, yang paling penting tidak perlu ganti air (zero water exchange) (Avnimelech, 2005). Teknologi bioflok dapat dilakukan dengan menambahkan karbohidrat organik kedalam media pemeliharaan untuk merangsang pertumbuhan bakteri heterotrof dan meningkatkan rasio $\mathrm{C} / \mathrm{N}$ (Crab et al., 2007).
Salah satu bakteri yang dapat digunakan untuk memperbaiki kualitas lingkungan tambak dan sekaligus bersifat sebagai bioflok adalah Bacillus subtilis. konsep bioflok dan penggunaan probiotik ini diharapkan mampu mengatasi permasalahan kualitas air dan pemenuhan protein pakan (Avnimelech: 1999). Tujuan dari penelitian ini adalah untuk mengetahui kombinasi dari perlakuan system bioflok yang optimal untuk pertumbuhan ikan nila (Oreochrois sp.).

\section{METODE PENELITIAN}

Penelitian ini dilaksanakan di Laboratorium Manajemen Kesehatan Hewan Akuatik Balai Besar Pengembangan Budidaya Air Payau (BBPBAP) Jepara.Bahan uji yang digunakan dalam penelitian ini adalah ikan nila Larasati (Oreochromissp.), bakteri Bacillus sp. dan Lactobacillus plantarum, pakan ikan komersial dengan kandungan protein 33,0851\% dan molase dengan kandungan karbon $29 \%$. Hewan uji yang digunakan adalah benih ikan nila larasati (Oreochromis sp.) yang didapatkan dari petani benih. Benih yang digunakan dalam penelitian ini ikan nila larasati tawar yang kemudian diadaptasi di air payau pada salinitas 5 ppt dan dilakukan aklimatisasi selama 4 minggu. masing-masing akuarium diberi ikan sebanyak 10 ekor, dengan padat tebar 3 liter/ekor. 
Metode yang digunakan dalam penelitian ini adalah eksperimental dengan skala laboratorium (Sedarmayanti dan Hidayat, S. 2002). Rancangan percobaan yang digunakan dalam penlitian ini adalah rancangan faktorial, dengan tiga kali perulangan.

Faktor

(perbandingan rasio $\mathrm{C}: \mathrm{N}$ ), yang terdiri dari 3 taraf rasio $\mathrm{C}: \mathrm{N}: 12,18$, dan 24; Faktor 2 (konsentrasi bakteri probiotik), yaitu terdiri dari dua taraf $10^{6}$ dan $10^{8} \mathrm{CFU} / \mathrm{ml}$. Penelitiuan ini terdiri dari enam perlakuan yaitu A1B1 (rasio $\mathrm{C}$ : $\mathrm{N}$ 12 + bakteri $\left.10^{6} \mathrm{cfu} / \mathrm{ml}\right) ; \mathrm{A} 1 \mathrm{~B} 2$ (rasio C: $\mathrm{N} 12+$ bakteri $10^{8} \mathrm{cfu} / \mathrm{ml}$ ); A2B1 (rasio C: N $18+$ bakteri $10^{6}$ $\mathrm{cfu} / \mathrm{ml}$ ); A2B2 (rasio C: N $18+$ bakteri $10^{8} \mathrm{cfu} / \mathrm{ml}$ ); A3B1 (rasio $\mathrm{C}$ : $\mathrm{N} 24$ + bakteri $\left.10^{6} \mathrm{cfu} / \mathrm{ml}\right) ;$ A3B2 (rasio C: $\mathrm{N} 24+$ bakteri $10^{8} \mathrm{cfu} / \mathrm{ml}$ ). Parameter yang diamati adalah Feed Conversion Ratio (FCR), perhitungan FCR menggunakan rumus Effendi (1997), yaitu sebagai berikut:

$F C R=\frac{F}{(W t+D)-W 0}$

Ketrangan:

$\mathrm{F} \quad$ : Jumlah pakan yang dikonsumsi selama

penelitian ( $\mathrm{g}$ )

FCR : Feed Conversion Ratio/ Konversi pakan

Wt: Biomassa ikan pada akhir penelitian

(g)

Wo: Biomassa ikan pada awal penelitian

(g)

D : Bobot ikan mati (g)

Selanjutnya, untuk mengetahui pengaruh rasio $\mathrm{C}: \mathrm{N}$ dan bakteri probiotik terhadap FCR dilakukan uji homogenitas, uji normalitas dengan metode KolmogorovSmirnor (Steel dan Torrie, 1995), uji additivitas dan analisis sidik ragam (Kusriningrum, 2008). Dilanjutkan dengan analisis varian (ANOVA) menggunakan SPSS versi 16. Apabila hasil menunjukkan berbeda nyata atau sangat nyata, maka dilanjutkan dengan uji lanjutan yaitu uji Beda Nyata Jujur (uji tukey). Uji lanjutan tersebut digunakan untuk mengetahui perlakuan mana yang paling berpengaruh pada suatu percobaan (Hanafiah, 2005).

\section{HASIL DAN PEMBAHASAN}

Pengaruh $\mathrm{C} / \mathrm{N}$ Rasio dan Bakteri Probiotik terhadap FCR Ikan Nila Larasati (Oreochromis sp.)

Data FCRikan nila larasati (Oreochromis sp.) pada setiap perlakuan selama pengamatan masa penelitian disajikan pada Tabel 1. Hasil penelitian FCR tertinggi dicapai oleh perlakuan $\mathrm{C} / \mathrm{N}$ Rasio 24 dan pada kepadatan bakteri probiotik $10^{8} \mathrm{CFU} / \mathrm{ml}$ yaitu sebesar 1,69, sedangkan FCR terendah pada C/N Rasio 18 dan kepadatan bakteri probiotik $10^{6}$ CFU/ml yaitu sebesar 1,56.

Table 1. Food Conversion Ratio (FCR) Ikan Nila Larasati (Oreochromis sp.) 


\begin{tabular}{|c|c|c|c|c|c|c|}
\hline \multirow{2}{*}{\multicolumn{2}{|c|}{ Perlakuan Ulangan }} & \multicolumn{4}{|c|}{ Kepadatan Bakteri } & \\
\hline & & $10^{6}$ & \multicolumn{4}{|c|}{$10^{8}$} \\
\hline & 1 & 1.67 & \multicolumn{4}{|c|}{1.60} \\
\hline $\mathrm{C} / \mathrm{N}$ rasio & 2 & 1.60 & \multicolumn{4}{|c|}{1.51} \\
\hline 12 & 3 & 1.61 & \multicolumn{4}{|c|}{1.72} \\
\hline & Rerata & $1.63 \pm 0.04$ & \multicolumn{4}{|c|}{$1.61 \pm 0.11$} \\
\hline & 1 & 1.56 & \multicolumn{4}{|c|}{1.67} \\
\hline $\mathrm{C} / \mathrm{N}$ rasio & 2 & 1.49 & \multicolumn{4}{|c|}{1.67} \\
\hline 18 & 3 & 1.63 & \multicolumn{4}{|c|}{1.50} \\
\hline & Rerata & $1.56 \pm 0.07$ & \multicolumn{4}{|c|}{$1.62 \pm 0.10$} \\
\hline & 1 & 1.87 & \multicolumn{4}{|c|}{1.64} \\
\hline $\mathrm{C} / \mathrm{N}$ rasio & 2 & 1.59 & \multicolumn{4}{|c|}{1.73} \\
\hline \multirow[t]{2}{*}{24} & 3 & 1.51 & \multicolumn{4}{|c|}{1.69} \\
\hline & Rerata & $1.66 \pm 0.19$ & \multicolumn{4}{|c|}{$1.69 \pm 0.05$} \\
\hline $\begin{array}{l}\text { Data FCR } \\
\text { perlakuan d } \\
\text { normalitas, } \\
\text { additifitas. } \\
\text { dengan ar }\end{array}$ & $\begin{array}{l}\text { pada } \mathrm{m} \\
\text { ianalisis te } \\
\text { homog } \\
\text { Kemudair } \\
\text { aalisis an }\end{array}$ & $\begin{aligned} \text { asing } & \text { mer } \\
\text { ahulu } & \text { (Ver } \\
\text { dan } & \text { bah } \\
\text { utkan } & \text { hom } \\
\text { ngan } & \end{aligned}$ & $\begin{array}{l}\text { gunak } \\
22,0) \\
\text { a dat } \\
\text { gen, d }\end{array}$ & $\begin{array}{l}\text { an pro } \\
\text { Berdas } \\
\text { ta meny } \\
\text { an bersifa }\end{array}$ & $\begin{array}{l}\text { gram } \\
\text { yerkan ha } \\
\text { at additif. }\end{array}$ & $\begin{array}{l}\text { SPSS } \\
\text { asil uji } \\
\text { ormal, }\end{array}$ \\
\hline $\begin{array}{l}\text { Tabel 2. Ha } \\
\text { Larasati (Ore } \\
\text { Tests of Bety } \\
\text { Dependent }\end{array}$ & $\begin{array}{l}\text { sil Analisis } \\
\text { ochromis s } \\
\text { veen-Subje } \\
\text { ariable:FC }\end{array}$ & (Anova) Food & onvers & sion Ratio & /FCR Ika & n Nila \\
\hline Source & & $\begin{array}{l}\text { Type III Sum } \\
\text { of Squares }\end{array}$ & Df & $\begin{array}{l}\text { Mean } \\
\text { Square }\end{array}$ & $\mathrm{F}$ & Sig. \\
\hline Corrected M & odel & $.028^{a}$ & 5 & .006 & .522 & .756 \\
\hline Intercept & & 47.564 & 1 & 47.564 & 4.402E3 & .000 \\
\hline $\mathrm{C}: \mathrm{N}$ rasio & & .022 & 2 & .011 & 1.025 & .388 \\
\hline Bakteri Prob & otik & .002 & 1 & .002 & .206 & .658 \\
\hline $\mathrm{C}: \mathrm{N}$ rasio ${ }^{*} \mathrm{~B}$ & akteri Prob & .004 & 2 & .002 & .176 & .840 \\
\hline Error & & .130 & 12 & .011 & & \\
\hline Total & & 47.722 & 18 & & & \\
\hline Corrected Tc & & .158 & 17 & & & \\
\hline
\end{tabular}

a. R Squared $=.179$ (Adjusted R Squared $=-.164$ ) 
Hasil analisis uji univariat anova menunjukkan bahwa perlakuan $\mathrm{C} / \mathrm{N}$ rasio, bakteri probiotik dan interaksi antara $\mathrm{C} / \mathrm{N}$ rasio dan bakteri probiotik tidak memberikan pengaruh yang nyata terhadap food conversion ratio (FCR) ikan nila larasati (Oreochromis sp.).

Perlakuan yang paling terendah adalah $\mathrm{C} / \mathrm{N}$ rasio 18 dan bakteri probiotik $10^{6}$ (A2B1) dibandingkan dengan perlakuan yang lainnya, tersaji pada grafik batang (Gambar 1).

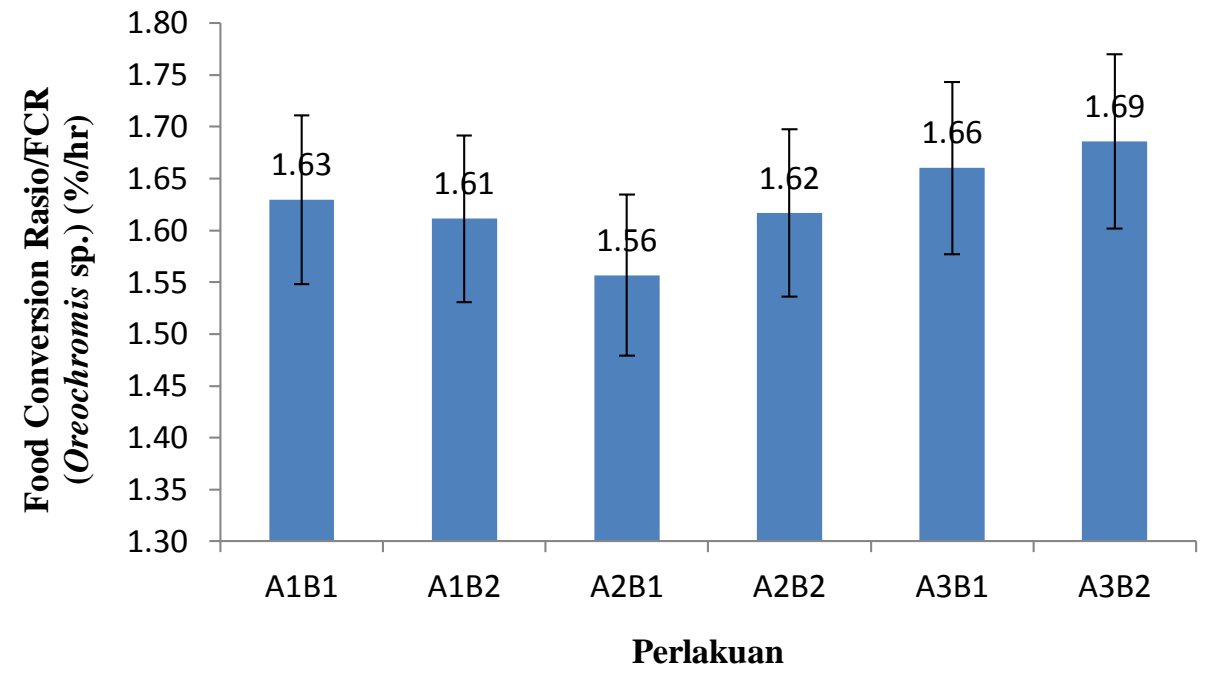

Gambar 1. Food Conversion Ratio (FCR) Ikan Nila Larasati (Oreochromis sp.)

\section{Kurva Respon}

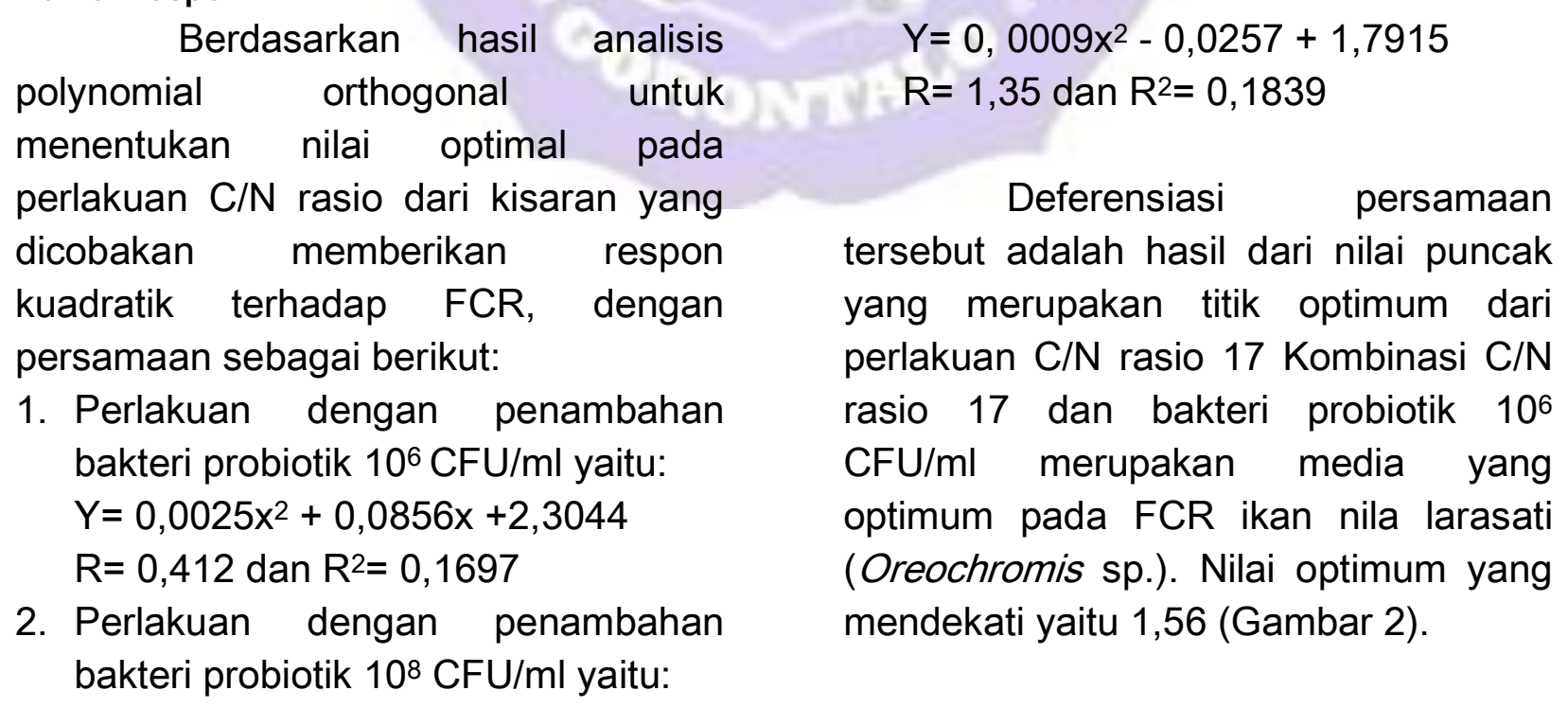




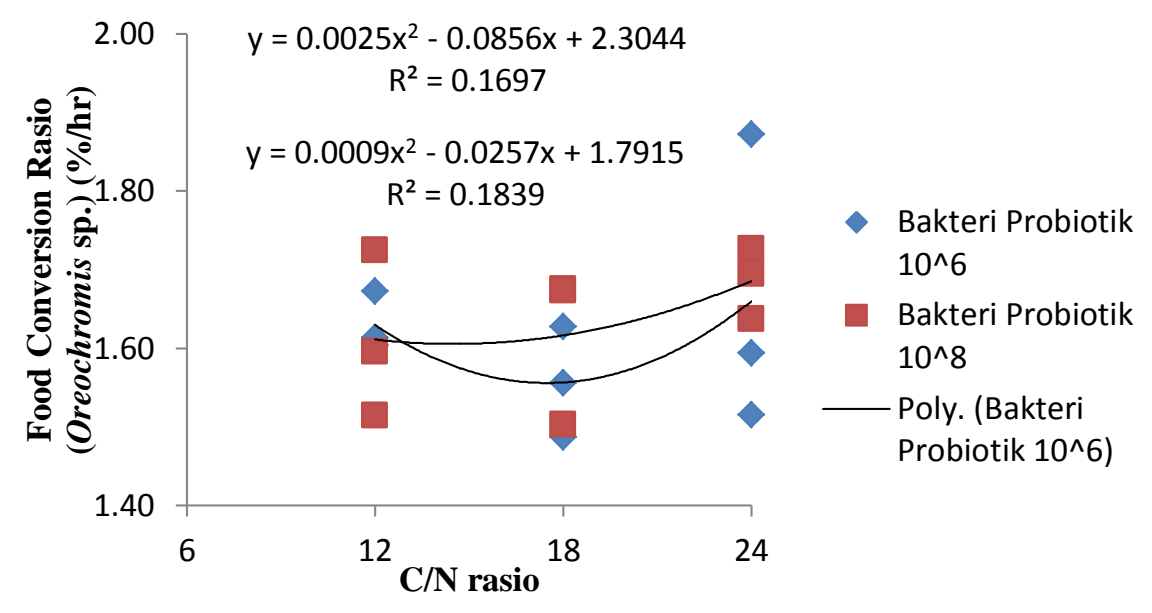

Gambar 2. Kurva Respon Kuadratik C/N Rasio Media pada Bakteri Probiotik terhadap FCR Ikan Nila Larasati (Oreochromis sp.)

Proses terjadinya bioflok adalah mengubah senyawa organik dan anorganik yang terdiri dari senyawa karbon $(C)$, hidrogen $(H)$, oksigen (O), nitrogen $(\mathrm{N})$, dan sedikit fosfor $(P)$ menjadi senyawa sludge berupa bioflok dengan menggunakan bakteri pembentuk flok (floc forming bacteria) yang mensintesis biopolymer polihidroksi alkanoat sebagai ikatan bioflok. Bakteri heterotrof diberikan guna membantu proses penguraian limbah nitrogen organik dari pakan dan sisa metabolisme untuk diubah menjadi biomassa bakteri (Schneider et al., 2006). Komunitas bakteri yang terakumulasi di dalam sistem akuakultur heterotrofik akan membentuk flok (gumpalan) yang dapat dimanfaatkan sebagai sumber pakan untuk ikan.

Perlakuan dengan sistem bioflok dengan penambahan bakteri probiotik memberikan pengaruh nyata pada FCR. Tersedianya flok sebagai pakan tambahan, maka kebutuhan pakan akan menjadi berkurang atau nilai dari FCR akan menjadi maksimal. Hal ini diduga karena kualitas air dan pemanfaatan pakan yang diberikan.Kualitas air selama masa pemeliharaan dalam keadaan yang optimum, sehingga pertumbuhan mikroba bioflok juga semakin cepat. Sesuai pendapat Wang (1999), menyatakan fungsi bakteri probiotik pada media budidaya yaitu mensetabilkan kualitas air dengan menurunkan bahan organik, amonia, gas hydrogen sulfide, dan bahan-bahan beracun 
lainnya. Selain itu,memperlihaatkan bahwa nilai FCR ikan nila larasati yang dipelihara dengan teknologi bioflok memenfaatkan pakan yang diberikan secara lebih efisien dan memanfaatkan bioflok sebagai pakan sumber protein. Julie, et.al. (2014) menyebutkan bahwa biofloc berukuran lebih besar dari $100 \mu \mathrm{m}$ mengandung protein $27,8 \%$, lipid $7,5 \%$, sedangkan biofloc berukuran lebih kecil dari $48 \mu \mathrm{m}$ kaya akan asam amino esensial.

Efisiensi pakan menjadi hal penting karena menunjang keuntungan para pelaku usaha perikanan. Efisiensi pakan merupakan penambahan berat basah ikan per unit berat kering pakan. Efisiensi pakan digunakan untuk mengetahui seberapa besar kenaikan bobot basah tubuh ikan dengan pakan yang dikonsumsi sebanyak satu gram. Kemampuan ikan untuk mencerna pakan yang dikonsumsi bergantung juga pada ada atau tidaknya enzim yang terkandung untuk bereaksi dengan substrat dalam saluran pencernaan. Penambahan bakteri pada pakan berpengaruh pada kecepatan fermentasi pakan dalam saluran pencernaan, sehingga membantu proses pencernaan dan penyerapan sari makanan.

Efisiensi pakan dapat diketahui dengan melihat nilai rasio efisiensi pakan. Menurut Haetami et al, (2007), kebutuhan protein ikan dipengaruhi oleh tingkat pemberian pakan dan kandungan energinya, sedangkan jumlah pemberian pakan dipengaruhi oleh kapasitas saluran pencernaan ikan, jika tingkat energi protein melebihi kebutuhan maka akan menurunkan konsumsi sehingga pengambilan nutrien lainnya termasuk protein akan menurun. Oleh karena itu diperlukan keseimbangan yang tepat antara energi dan protein agar dicapai keefisienan dan keefektifan pemanfaatan pakan.

Kandungan energi dalam bioflok, baik yang berasal dari protein, lemak dan karbohidarat meningkatkan ketersediaan energi yang dapat dikonsumsi oleh ikan. $\mathrm{Hal}$ ini mengoptimalkan ikan dalam memanfaatkan protein untuk meningkatkan biomasa. Kandungan protein dalam bioflok juga meningkatkan ketersediaan energi protein yang dikonsumsi oleh ikan untuk pertumbuhan. Energi yang berasal dari protein digunakan untuk pembentukan sel, pertumbuhan, reproduksi dan sumber energi. Energi yang berasal karbohidrat dan lemak digunakan untuk metabolisme dan perawatan. Hal ini sesuai dengan pendapat Affandi dan Tang (2002), bahwa jika energi yang dibutuhkan oleh udang dari karbohidrat dan lemak, maka energi yang berasal dari protein digunakan untuk pertumbuhan dan 
reproduksi. Pertumbuhan terjadi jika energi bersih (net energy) dari energi yang dikonsumsi lebih besar daripada energi yang digunakan untuk menopang aktivitas hidup dan proses lainnya (maintenance energy).

Setiap spesies ikan berbeda kebutuhannya terhadap protein dan energi (Suhenda, 2005). Kebutuhan ikan akan energi sebagian besar dipenuhi oleh nutrien non-protein seperti lemak dan karbohidrat, apabila energi yang berasal dari sumber nonprotein cukup tersedia maka sebagian besar protein akan dimanfaatkan untuk tumbuh, namun apabila energi dari nonprotein tidak terpenuhi maka protein akan digunakan sebagai sumber energi sehingga fungsi protein sebagai pembangun tubuh akan berkurang (Adelina, 2000). Kebutuhan pakan berenergi begitu penting dalam menejemen kualitas pakan. Ikan membutuhkan energi untuk pertumbuhan, aktivitas hidup dan perkembangbiakan. Ikan menggunakan protein sebagai sumber energi yang utama, sumber energi kedua yang 2 digunakan adalah lemak, sedangkan karbohidrat menjadi sumber energi yang ketiga. Pengembangan budidaya perikanan dapat dilaksanakan jika aspek pakan untuk jenis ikan tersebut diketahui, sehingga para pelaku usaha perikanan dapat menentukan formulasi pakan yang tepat dengan berpedoman pada kebutuhan nutrien dan mutu bahan makanan. Nutrien tersebut digunakan untuk sintesis (anabolisme) dan sebagai sumber energi (katabolisme).

\section{PENUTUP}

\section{Simpulan}

Penambahan $\mathrm{C} / \mathrm{N}$ rasio dan bakteri probiotik untuk yang interaksi berpengaruh nyata hanya pada FCR (Oreochromis sp.) dan optimum pada perlakuan $\mathrm{C} / \mathrm{N}$ rasio 18 dengan penambahan bakteri probiotik $10^{6} \quad \mathrm{CFU} / \mathrm{ml}$, menghasilkan sebesar 6,60 gram, serta memberikan pengaruh yang tidak nyata $(p>0,05)$ pada energi ikan nila larasati

\section{Saran}

Perlakuan yang terbaik adalah pada interaksi C/N 24 dan bakteri probiotik $10^{8}$, sedangkan pemberian bakteri probiotik $10^{6}$ belum memberikan hasil yang maksimal/ nyata, maka diperlukan penelitian lebih lanjut terhadap konsentrasi bakteri probiotik pada budiaya ikan nila (Oreochromis sp.) dengan aplikasi bioflok.

\section{DAFTAR PUSTAKA}

Adelina. 2000. Pengaruh Kadar Protein dan Rasio Energi Protein Pakan Berbeda Terhadap Kinerja pertumbuhan Benih Ikan Bawal Air Tawar Colossome Volume 7 Nomor 1 Tahun 2018 


\section{macropomum). (Skripsi). Jurusan Perikanan. IPB. 39 hlm. \\ Affandi, R.and U.M. Tang. 2002. Fisiologi Hewan Air. Badan Penerbit Universitas Riau (unri Press), Pekanbaru. $217 \mathrm{hlm}$.}

Asaduzzaman, M., M.A. Wahab, M.C.J. Verdegem, S. Huque, M.A. Salam, and M.E. Azim. 2008. C/N Ratio Control and Substrate Addition for PeriphytonDevelopment Jointly Enhance Freshwater Prawn (Macrobrachium rosenbergi) Production in Ponds. Aquaculture, 280: 117-123.

Avnimelech, $\quad$ Y. 1999. Carbon/Nitrogen Ratio as a Control Element in Aquaculture Systems. Aquaculture 176:227-235.

and G. Ritvo. 2003. Shrimp and Fish Pond Soils: Processes and Management. Aquaculture 220:549-567.

http://dx.doi.org/10.1016/S0 044-8486(02)00641-5

- 2005. Tilapia Harvest Microbial Flocs in Active Suspension Research
Pond. Glob. Aquac. Advocate. October 2005. 57-58 pp. 2009. Biofloc Technology: A Practical Guide Book. World Aquaculture Society: Louisiana, USA. 120 p.

de Schryver, P., R. Crab, T. Defoirdt, N. Boon, and W. Verstraete. 2008. The Basics of Bio-Flocs Technology. The Added Value for Aquaculture. Aquaculture, 277: 125-137 pp.

FAO. 2014. The State of World Fisheries and Aquaculture 2006. FAO, Rome. 162 p.

Effendi, H. 1997. Biologi Perikanan. Yayasan Pustaka Nusatama: Yogyakarta. $163 \mathrm{hlm}$.

Hanafiah, K. A. 2005. Rancangan Percobaan. Raja Grafindo Persada. Jakarta. 223 hlm.

Haetami, K. 2007. Kebutuhan dan pola makan ikan jambal siam dari Berbagai tingkat pemberian energi protein Pakan dan pengaruhnya terhadap pertumbuhan Dan efisiensi.

Laporan

Penelitian.

Fakultas

Perikanan dan IImu 
Kelautan Universitas

Padjadjaran. Bandung. 39 hlm.

Julie, E., D. Angela, S.H. Waluyo, T. Bachtiar, and E. Harris, 2014. The zise of biofloc determines the nutritional composition and the nitrogen recovery by aquaculture animals. Aquaculture, 426-427:105$111 \mathrm{pp}$.

Kusriningrum, R. 2008. Buku Ajar Perancangan Percobaan. Universitas. Airlangga. Surabaya. $38 \mathrm{hlm}$.

Schneider, O., V. Sereti, E.V. Eding, and J.A.J. Verreth. 2006. Molasses As C Source For Heterotropic Bacteria Production On Solid Fish Waste. Aquaculture 261: 12391248.
Sedarmayanti dan S. Hidayat. 2002. Metodologi Penelitian. Bandung. Mandar Maju. $121 \mathrm{hlm}$.

Steel, R.G.D and J.H. Torrie. 1995. Prinsip dan Prosedur Statistika. Suatu Pendekatan Biometrik. Penerbit PT. Gramedia Pustaka Utama. Jakarta, 56-62p.

Suhenda. 2005. Pertumbuhan benih ikan patin jambal yang diberi pakan dengan kadar protein berbeda. Berita Biologi Jurnal IImiah Nasional. 7(4): 191-197.

Wang, Y. C. 1999. Health Management of Shrimp During Grow-Out. Info Fish Internasional, 4:

33-36. 